\title{
Bovine Early Embryonic Development and Vitamin A
}

\author{
E Gómez, JN Caamaño, A Rodríguez, C De Frutos, N Facal and C Díez \\ Servicio Regional de Investigación y Desarrollo Agroalimentario, (SERIDA), Área de Genética y Reproducción, SERIDA, Asturias, Spain
}

\begin{abstract}
Contents
Vitamin A and its derivatives, collectively termed as retinoids, have been paid attention in recent years because of their effects in bovine reproduction. However, the role of retinoids in the preimplantatory period continues to be largely unexplored, in contrast to later stages of development. Retinoids control cell growth, differentiation and death through binding to specific nuclear receptors by retinoic acid and other active metabolites. This paper reviews how retinoids can influence early embryonic development in cattle through their influence on the follicle, the extrafollicular oocyte and the pre-implantatory embryo itself.
\end{abstract}

\section{Uptake and Storage of Vitamin A}

Nature only furnishes vitamin A (all-trans-retinol; $\mathrm{ROH}$ ) as a result of enzymatic action on certain carotenoid precursors that takes place within the bodies of most vertebrates. Carotenoids are found in many plants and animals, but no animal is able to synthesize carotenoids. Of these, $\beta$-carotene (BC; provitamin A) makes by far the largest contribution to vitamin A activity in foodstuffs. Collectively, vitamin A and its derivatives are known as retinoids. Cows take up vitamin A as naturally contained $\mathrm{BC}$ in forages or as a diet supplementation with esterified ROH (NRC Nutrient requirements on Beef -2000- and Dairy -2001- cattle). The ROH metabolism has been reviewed by McLaren and Frigg (2001); http://www.sightandlife.org), and recently in cattle reproduction by Ikeda et al. (2005). Retynil esters are hydrolized in the intestinal mucosa to produce $\mathrm{ROH}$, which is then absorbed by enterocytes. However, BC passes directly into the mucosal cells unchanged and gives two molecules of retinal (RAL) by symmetrical cleavage. Retinal is mostly reduced and esterified to retinyl ester, which is packaged into aggregates of lipids with fat-soluble vitamins and some apolipoproteins termed as chylomicrons. Chylomicrons pass into the lymph and subsequently into the blood, to be broken down in chylomicron remnants, which are mainly cleared by the liver. Cattle have from $70 \%$ to $90 \%$ of their total vitamin A stores in the liver, an organ crucial in retinoid storage and metabolism, but there exist important retinoid reserves stored in the fat tissue, as demonstrated in rats (Bonet et al. 2003). Hepatocytes take up most vitamin A from chylomicron remnants as retinyl esters. The produced $\mathrm{ROH}$ is transported where required by retinol binding proteins (RBP), forming a ternary complex bound to transthyretin in blood (Ingenbleek and Young 1994). On its side, ROH in the adipocyte can be derived from hydrolysis of retinyl esters of chylomicrons (Blaner et al. 1994) or taken out from circulating $\mathrm{ROH}$. There are no specific carrier proteins for carotenoids, which circulate in the cow bound to lowdensity lipoproteins (LDLs) (Schweigert et al. 1987;
Schweigert and Eisele 1990) and enter cells bearing the LDL receptor.

\section{Intracellular Metabolism of Retinoids}

The members of the retinoid family play a fundamental role as the regulators of cell growth, embryonic morphogenesis and differentiation in many types of cell. Through a series of oxidative reactions, vitamin A generates the retinoic acid (RA) isomeres all-trans-RA (ATRA) and 9-cis-RA. The isomere ATRA is the most important $\mathrm{ROH}$ metabolite for vertebrate embryogenesis (Morriss-Kay and Ward 1999; Ross et al. 2000). Levels of RA are locally regulated by retinaldehyde dehydrogenases, which catalyse the last step of RA synthesis and by the cytochrome P450, 26 family of enzymes (CYP26), which degrade RA. In the live cell, RA binds to two different kinds of nuclear receptors, namely, retinoic acid receptors (RARs) and retinoid X receptors (RXRs), each having subtypes $\alpha, \beta$, and $\gamma$. The access of RA to the cell nucleus is controlled by cellular retinoic acid-binding proteins (CRABP) that protects against the RA excess. Upon entering the nucleus, ATRA and 9-cis RA can activate RARs, whereas RXRs are activated only by 9-cis-RA (Mangelsdorf et al. 1994; Chambon 1996). Heterodimerization between RXR and RAR or other members of steroid/thyroid hormone nuclear receptors superfamily (Chambon 1996), can occur in response to ligand-mediated activation. Heterodimers are capable of binding to specific DNA sequences named retinoic acid response elements (RAREs), to increase or decrease the expression of a gene. Several components of the RA signalling pathway such as $\operatorname{RAR} \alpha$ and $\gamma, \operatorname{RXR} \alpha$ and $\beta$, retinaldehyde dehydrogenase (ALDH) and the RXR-heterodimer, peroxisome-proliferator activated receptor gamma (PPAR $\gamma$ ), are expressed in bovine oocytes and embryos (Mohan et al. 2001,2002) and in cumulus cells (Mohan et al. 2003). Expression of $\operatorname{RXR} \alpha, \beta$ and $\gamma$ is higher in the oocyte and before major genome activation in vitro, while it strongly decreases ( $\operatorname{RXR} \alpha$ and $\beta$ ) or irregularly expresses $(\mathrm{RXR} \gamma)$ from the 8-cell to the blastocyst stage in vitro (Mamo et al. 2005). Within in vivo embryos, $\mathrm{RXR} \gamma$ show a pattern similar to that observed in vitro for RXR $\alpha$ and $\beta$ (Mamo et al. 2005). The former authors also found that all RXR subtypes show increased expression in good quality oocytes and 2- and 4-cell embryos. Immunostaining detected $\operatorname{RAR} \alpha$, and $\beta$ in blastocysts (Mohan et al. 2001,2002) and $\operatorname{RAR} \alpha$ and $\operatorname{RXR} \beta$ in cumulus cells (Mohan et al. 2003). Thecal, granulosa and luteal cells synthesize and secrete RBP (Brown et al. 2003). Therefore, several ways exist for retinoids to influence embryonic development. 


\section{The Retinoids and the Follicle}

The oocyte itself is under the retinoid influence within their intrafollicular growth, as the bovine follicular fluid (FF) contains ROH and BC (Chew et al. 1984; Schweigert and Zucker 1988; Haliloglu et al. 2002; Hidalgo et al. 2005; our unpublished results) in proportion to the respective blood contents (Chew et al. 1984; Haliloglu et al. 2002; Hidalgo et al. 2005; our unpublished results). Retinol and $\mathrm{BC}$ can diffuse freely between plasma and $\mathrm{FF}$, but also bind to carrier molecules (Schweigert and Zucker 1988; Brown et al. 2003), which could explain in part the differences in concentration seen between both compartments. In cattle, large and medium size follicles contain higher $\mathrm{ROH}$ concentrations than follicles $\leqslant 3 \mathrm{~mm}$ in diameter (unpublished results). Accordingly, expression of the CRABP II has been found in the rat, which is confined to granulosa cells from mature follicles and luteal cells (Bucco et al. 1995; Wardlaw et al. 1997; Zheng et al. 1999), but not found in other species. The late intrafollicular expression of CRABP II could mean that mature follicles need a more stringent RA regulation, which would be consistent with an increased RA synthesis in follicles bearing higher $\mathrm{ROH}$ contents.

It has been proposed in cattle that specifically reproductive effects of $\mathrm{BC}$ cannot be mimicked by supplemented vitamin A (reviewed in Ikeda et al. 2005). Although controversial, these authors suggest that exogenous $\mathrm{BC}$ can improve the conception rate in artificial insemination (AI) under certain stress or deprivation conditions (low $\mathrm{BC}$ diet, high milk production and heat stress). Further studies showed that cows with lower plasma BC had a reduced reproductive performance (Gossen and Hoedemaker 2005), and the exogenous use of $\mathrm{BC}$ was thus discouraged (Gossen et al. 2004). In superovulated cows, no clear benefits of $\mathrm{BC}$ on embryo production was found (Martínez-Bello et al. 2004), although cows with higher BC gave more transferable embryos (Goto et al. 1989, cited in Ikeda et al. 2005). It is difficult in these reports to distinguish the target of retinoids, as effects can be exerted on the intrafollicular oocyte, the ovulated oocyte, the proper early embryo or both the oocyte and the embryo. This also occurs when the developmental competence of the oocyte is enhanced by a ROH treatment in the cow (Shaw et al. 1995), sheep (Eberhardt et al. 1999) and gilt (Whaley et al. 1997,2000), as well as in rabbits that have high blood levels of vitamin A (Besenfelder et al. 1996). The effects of $\mathrm{ROH}$ on follicular development were usually monitored and recorded 4-day post-administration (Shaw et al. 1995; Whaley et al. 1997,2000; Eberhardt et al. 1999). The reasons why these standards were set are not described and the limits (length and dosage) of ROH treatment are unknown. Similarly, the ability of blastocysts resulting from oocytes of domestic females treated with exogenous $\mathrm{ROH}$ to establish and maintain pregnancy was so far unexplored. Development of these blastocysts after transfer to recipients is worth testing as disturbances in retinoid homeostasis have been linked to developmental abnormalities (reviewed by Zile 2001). The above challenges can be tested in part by treating oocyte donor cows with $\mathrm{ROH}$, as those oocytes aspirated from the follicle would develop free from the effects of tissular $\mathrm{ROH}$ when cultured in vitro up to the blastocyst stage. Recent work from our group (Hidalgo et al. 2005) analysed the effects of $\mathrm{ROH}$ directly on the oocyte during its intrafollicular growth, the time limits of exposure to exogenous ROH and the viability of these oocytes. Heifers injected once with $1 \times 10^{6} \mathrm{ROH}$ IU showed blood ROH increased by Day 1 after the injection and clearance on Day 4, but ROH remained higher within the follicle, showing that monitoring of blood $\mathrm{ROH}$ is not indicative of the actual $\mathrm{ROH}$ status in reproductive tissues. Thereafter, oocyte donors were injected four times in a week with $\mathrm{ROH}$ or vehicle during a twice per week cycle of eight recovery sessions (starting 4 days before the first session), followed by a second 8-session cycle without treatment. The oocytes were retrieved from the cow by Ovum-Pick-Up and fertilized and cultured in vitro. Retinol treatment yielded higher numbers of low quality oocytes throughout, while total oocytes, morulae and blastocyst rates increased during the first five sessions of treatment with $\mathrm{ROH}$. Following transfer to recipients, blastocysts from oocytes exposed to $\mathrm{ROH}$ were unable to establish pregnancy. As previously shown with oocytes from slaughterhouse ovaries (Hidalgo et al. 2003), the presence of 9-cis-RA during in vitro maturation (IVM) stimulated blastocyst development and led to pregnancies. The effect of ROH on the intrafollicular oocyte in the cow was confirmed and provides an early evidence regarding the teratogenic effect of $\mathrm{ROH}$. The quality of bovine follicles, measured as degree of atresia, negatively correlates with $\mathrm{ROH}$ contents in the follicle, while estradiol concentration directly correlates with that of $\mathrm{ROH}$ (Schweigert and Zucker 1988). These are evidences of ROH regulation of final follicular development, which is dependent on gonadotropins at these stages.

\section{Retinoids and In Vitro Maturation}

In bovine, we and other authors have studied the role of ROH of during IVM using a medium based on TCM199 (Gómez et al. 2002; Lawrence et al. 2004; Livingston et al. 2004). These conditions are probably no optimal, as TCM199 contains over $0.4 \mu \mathrm{M}$ vitamin A acetate, which could mask in part the effects of $\mathrm{ROH}$ added for experimental purposes. In spite of these adverse conditions, Livingston et al. (2004) found that ROH $5 \mu \mathrm{M}$ improved the blastocyst development within a subgroup of replicates whose controls exhibited lower efficiency in reaching the blastocyst stage, as well as tended to improve the blastocyst development when all replicates were analysed as a pool. The above research group demonstrated that ROH $5 \mu \mathrm{m}$ during IVM prevents a reduction in blastocyst rates in heat-stressed oocytes (IVM performed at $41{ }^{\circ} \mathrm{C}$ ) as compared with oocytes matured at physiological temperature $\left(38^{\circ} \mathrm{C}\right)$ (Lawrence et al. 2004). We found no effects with ROH $0.5 \mu \mathrm{m}$ (Gómez et al. 2002). Collectively, the above data suggest that $\mathrm{ROH}$ can protect oocytes from certain perturbing conditions and stress, and that appropriate maturation conditions could contribute to clarify the effects of $\mathrm{ROH}$ on non-stressed oocytes. 
The disruption of retinoid homeostasis by exogenous ATRA or deprivation of RA has been associated with late developmental abnormalities as the normal relationship between cellular retinoid levels and the genetic developmental programme is altered (Griffith and Zile 2000; Roberts et al. 2005). The enzyme ALDH generates the majority of RA. Experimental inhibition of RA production in null mutations of ALDH (Niederreither et al. 1999) or its chemical inhibition using citral, a generic ALDH competitive antagonist (Griffith and Zile 2000; Iwata et al. 2004; Song et al. 2004), is followed by developmental defects and death. Phenotypes produced by the inhibition of ALDH can be rescued by ATRA supplementation. The bovine COC contains an undetermined amount of $\mathrm{ROH}$. A dose-response study with citral during IVM resulted in a gradual inhibition in development of the fertilized oocyte by increasing $\mu \mathrm{M}$ concentrations of citral (Table 1). Preliminary results point out that the inhibitory effect of citral in the COC can be reverted by RA (unpublished), such as the one which occurs in the early embryo (Rodríguez et al. 2006). These results are not unexpected, as a number of cell types contain $\mathrm{ROH}$ esterified in the form of fatty acids (Bonet et al. 2003). Bovine oocytes show high triglyceride levels (Ferguson and Leese 1999; Leroy et al. 2005), which increase in embryos during in vitro culture with serum (Ferguson and Leese 1999; Leroy et al. 2005) and remain relatively constant in embryos cultured in the absence of serum (Ferguson and Leese 1999). Therefore, ROH stored in the oocyte might be made functionally active through the conversion to RA, both during IVM and during the blastocyst development, as will be described here.

The developmental competence of the oocyte can be improved both during IVM and during an induced meiotic arrest. The purpose of inhibiting meiosis in vitro is to allow for stable mRNA and protein accumulation in the cytoplasm. This culture period, also termed as pre-maturation, presents a window of opportunity for transcription factors such as RA to act. Treatment with 9-cis-RA $5 \mathrm{~nm}$ during meiotic inhibition alone was more effective than treatment during IVM alone or during both periods (Duque et al. 2002). The so-treated oocytes showed partial cytoplasmic granular migration prior to IVM, and complete granular migration after IVM, resembling that observed in oocytes matured in vivo. On the other hand, blastocyst development rates as well as survival rates of cryopreserved blastocysts were improved when the oocyte received 9-cis-RA during pre-maturation. The benefits of this treatment extended to total cell numbers. Conversely, a retinoid overexposure (i.e. 9-cis-RA both during pre-maturation and IVM), was detrimental for the oocyte in all the above analysed parameters.

In a later study during a non-inhibited, conventional IVM (Gómez et al. 2003), the presence of 9-cis-RA $5 \mathrm{~nm}$ gave a completely migrated cortical granule and improved the blastocyst development, while $500 \mathrm{~nm}$ was toxic. The ability of vitrified blastocysts to survive in vitro was not improved by 9 -cis-RA. Nevertheless, as only blastocysts obtained from oocytes matured with serum survived, more factors should be considered when evaluating cryopreservation survival. The complete granular migration observed in oocytes matured with 9-cis-RA anticipates a gain in the developmental competence of the oocyte. Contrary to controls, blastocysts obtained from oocytes matured in vitro in chemically defined conditions with 9-cis-RA led to pregnancies (Hidalgo et al. 2003).

\section{Retinoids and Embryonic Development}

Few studies have analysed the direct influence of retinoids on embryonic development on mammalian species both in vitro and in vivo. Researches on retinoids have classically focused on late development stages, probably because the striking, wide spectrum of malformations in the offspring of humans (Guillonneau and Jacqz-Aigrain 1997), rodents (Shenefelt 1972; Kessel and Gruss 1991), chickens (Thaller and Eichele 1987) and Xenopus (Durston et al. 1989; Sive et al. 1990), exert considerable attraction for the researchers. Alterations include defects in neural tube and central nervous system, skeleton, cleft palate, ear and multiple craniofacial malformations, heart, thymus, urogenital system, limb and digit reduction or duplication. Normal development requires retinoids, but deficiency or excess at the improper stage or time can be detrimental to the developing embryo (Sporn and Roberts 1991).

Eberhardt et al. (1999) injected ROH to donor ewes at the time of FSH administration and recovered embryos both at the 1- to 4-cell stage and at the morula to blastocyst stage. In both stages, embryos recovered from ROH-treated donors formed blastocysts and hatched at higher rates, although ovulation and fertilization rate were unmodified. As reported above, it is
Table 1. Presence of citral during in vitro maturation of bovine oocytes

\begin{tabular}{rrrrrr}
\hline & & & & \multicolumn{2}{c}{ Blastocysts (\%) } \\
\cline { 5 - 6 } Citral & $\mathrm{N}$ & $\mathrm{R}$ & Cleaved & Day 7 & Day 8 \\
\hline $0 \mu \mathrm{M}$ & 267 & 7 & $85.4 \pm 4.7$ & $21.5 \pm 2.8^{\mathrm{a}}$ & $21.5 \pm 2.6^{\mathrm{a}}$ \\
$10 \mu \mathrm{M}$ & 204 & 6 & $67.3 \pm 5.2$ & $17.1 \pm 3.1$ & $19.0 \pm 3.0$ \\
$50 \mu \mathrm{M}$ & 205 & 6 & $72.0 \pm 5.2$ & $17.3 \pm 3.1$ & $17.3 \pm 3.0$ \\
$200 \mu \mathrm{M}$ & 270 & 7 & $75.3 \pm 4.7$ & $9.5 \pm 2.8^{\mathrm{b}}$ & $10.2 \pm 2.6^{\mathrm{b}}$ \\
\hline
\end{tabular}

One-way ANOva; LSM \pm SEM.

Different superscripts a, b express significant differences $(\mathrm{p}<0.02)$.

Maturation medium consisted of Synthetic Oviduct Fluid (SOF) with $0.5 \mu \mathrm{g} / \mathrm{ml}$ Polyvynil-alcohol, and FSH, luteinizing hormone and E2. Oocytes were fertilized in vitro with frozen/thawed semen and cultured in SOF, amino-acids, citrate and myo-inositol, with $10 \%$ FCS up to Day 8 under $5 \% \mathrm{CO} 2$ and $5 \% \mathrm{O} 2$.

$\mathrm{N}$, Cumulus-oocyte complexes cultured; R, replicates. 
difficult to distinguish the ROH influence on the oocyte or the embryonic development when donors and not the oocyte or the embryo are treated with retinoid. Just recently studies dealing with effects of retinoid on blastocyst development have been accomplished in mice. Huang et al. $(2001,2003,2005,2006)$ developed a series of experiments with the aim to demonstrate that the early developmental stages in the mouse were also susceptible to the retinoid damage. These researchers worked with low $(0.1 \mu \mathrm{M})$ and high $(10 \mu \mathrm{M})$ RA dosages, omitting concentrations of RA that could be considered as physiological $(0.3-1 \mu \mathrm{M})$. These experiments are particularly useful when looking for beneficial effects of retinoids, as embryos exposed to RA develop characteristic dose-dependent defects. In cultured mice blastocysts ATRA $10 \mu \mathrm{M}$ exerts anti-proliferative and proapoptotic effects, which can result in subsequent retardation of post-implantation development (Huang et al. 2001,2003,2006). These effects were mainly targeted to the inner cell mass (ICM; Huang et al. 2005). However, in cattle embryos produced entirely in vitro, blastocyst development rates improve in simple medium under atmospheric conditions, in contrast to embryos cultured under low oxygen conditions (Livingston et al. 2004). This study demonstrated that anti-oxidant defense mechanisms can be affected by retinoids during embryonic development. Recently, we investigated a part of the above effects using an in vitro model to analyse the effect of exogenous and endogenous retinoids on blastocyst development (Rodríguez et al. 2006). We examined the morula to hatched blastocyst transition starting from Day-6 morula produced in vitro. After a $24 \mathrm{~h}$ treatment, ATRA $0.7 \mu \mathrm{M}$ increased the proliferation both in the ICM and trophectoderm (TE), without affecting the apoptosis rate, but reducing necrosis and maintaining the ICM/TE cell ratio. In the mammalian blastocyst, the ICM has a higher apoptotic ratio than the $\mathrm{TE}$, which has been suggested to occur naturally to eliminate non-committed cells (Gjorret et al. 2003; Davidson et al. 2004). An evidence of increased apoptotic activity in the ICM can be observed in Fig. 1a,b. Our results in cattle are in contrast to the detrimental effects of ATRA $10 \mu \mathrm{M}$ in mice (Huang et al. 2001,2003,2006). Differences could depend on 5\% serum and $0.7 \mu \mathrm{M}$ RA we used (Rodríguez et al. 2006), while the above mouse studies were performed in the absence of serum or BSA. It was reported that release of ATRA is physiological and slower in culture with serum proteins, as is its uptake by cells (Klaassen et al. 1999). The slow release of ATRA from proteins was confirmed in morulae cultured with very high BSA concentrations ( $\cong 20 \mathrm{mg} / \mathrm{ml}$ ), where physiological doses of ATRA had no effect on development and cell counts (unpublished results). A hatched blastocyst cultured with ATRA and BSA, fixed and stained for differential cell counts (Thouas et al. 2001), can be seen in Fig. 2.

The endogenous conversion of RA from $\mathrm{ROH}$ is essential throughout the development, although the $\mathrm{ROH}$ and RA concentrations in the bovine blastocyst are unknown. However, the porcine blastocyst at Day 10 contains RA $(36.2 \mathrm{~nm}$ in the whole embryo and $35.4 \mathrm{~nm}$ in the TE) and $\mathrm{ROH}(48.9 \mathrm{~nm}$ in the whole embryo and $122.3 \mathrm{~nm}$ in the TE) (Parrow et al. 1998).
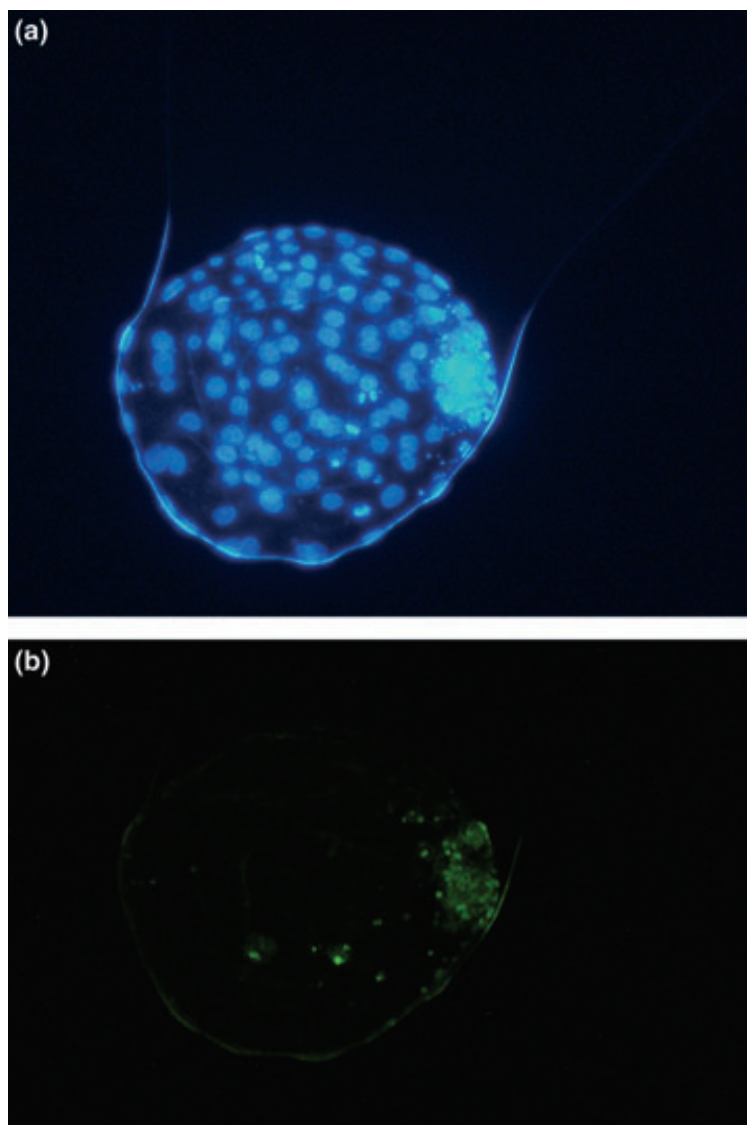

Fig. 1. Bisbenzimide (a) staining and TUNEL (b) images within a bovine blastocyst. Apoptotic nuclei display peculiar shape and TUNEL positive reaction, being more abundant in the inner cell mass region

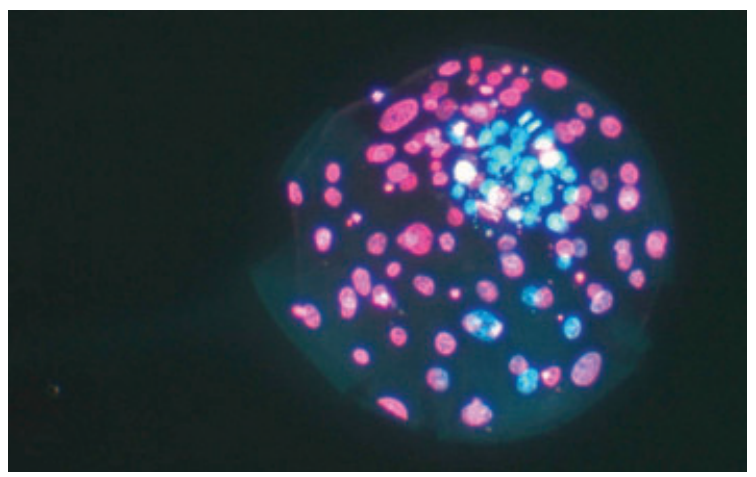

Fig. 2. Hatched blastocyst fixed and stained for differential cell counting as described by Thouas et al. (2001). Blastocysts were incubated in medium with Triton $\times-100$ and propidium iodide, and then fixed in ethanol with bisbenzimide (Hoechst 33342). Trophectoderm cells were identified by their red fluorescence; inner cell mass appears blue

These levels are functionally active, and a higher $\mathrm{ROH}$ contents in the TE is consistent with tissues undergoing active differentiation (Schweigert et al. 2002). Endogenous retinoids in the embryonic cells can derive from the culture environment, the originating oocyte or both. In co-cultures, RA can be secreted by cultured cells (Parrow et al. 1998; Dirami et al. 2003) from internal 
ROH stores. When endogenous RA synthesis in Day 6 bovine morulae was inhibited with citral $150 \mu \mathrm{M}$, blastocyst development decreased at all stages analysed, being the effect of citral reversed by ATRA $0.7 \mu \mathrm{M}$ in a specific manner, as ATRA $0.7 \mu \mathrm{M}$ alone had no effect (Rodríguez et al. 2006). From their ROH stores, bovine embryonic cells produce active retinoid metabolites that certainly appear to regulate development, differentiation and cell death at early stages, although the true dimension of the retinoid stock is still unknown. These results are in support of a role for ATRA as the only ligand clearly necessary for retinoid receptor signalling (Mic et al. 2003). However, although more than physiological doses of ATRA are needed to detect cellular concentrations of 9-cis-RA (Ulven et al. 2001; Mic et al. 2003), isomerization of ATRA to 9-cis-RA can occur in culture (Klaassen et al. 1999). As information on RXRs and 9-cis-RA is scarce and focused on later embryonic stages in the mouse (Mangelsdorf et al. 1992; Dolle et al. 1994; Romert et al. 1998), we wished to analyse the so-called second retinoid pathway. However, the unspecific binding of 9-cis-RA to both RAR and RXR receptors made it difficult to study $R X R$ transactivation, so we used a specific synthetic RXR agonist [LG100268 (LG); a gift of Ligand Laboratories, MI, USA] to study the blastocyst development and differentiation in a preliminary report (Gómez et al. 2006). Subsequent experiments (unpublished) point out that Day-6 morulae cultured for $48 \mathrm{~h}$ with low $\mu \mathrm{M}$ LG concentration show improved blastocyst development, hatching and diameter at full expansion, while cell counts remain unaffected. However, high LG concentration had no effect on blastocyst development and diameter, but reduces TE, increases ICM and alters the ICM/total cells ratio. These studies with a RXR specific agonist will be replicated at earlier embryonic stages, where expression of RXRs is dramatically higher than in morulae and blastocysts (Mamo et al. 2005).

\section{Responses to Retinoids at the Gene Level}

Retinoids act to induce or silence the expression of hundreds of genes, and little is known of the normal chain of events within an intact tissue. In cattle oocyte and embryonic development not many authors have been able to provide a physiological explanation of the observed effects of retinoids (Ikeda et al. 2005), and the number of genes analysed is scarce.

Granulosa and cumulus cells express retinoid responsive genes, and retinoids undoubtedly influence the oocyte growth by acting on the surrounding cells. Gonadotropins regulate the differentiation status of granulosa cells and controls follicle development. Granulosa cells express gonadotropin receptors FSH-receptor (FSH-R) and LH-receptor (LH-R), and RA suppress the expression of FSH-R (Minegishi et al. 1996,2000a; Xing and Sairam 2002) and LH-R (Bagavandoss and Midgley 1988; Hattori et al. 2000; Minegishi et al. 2000b) induced by FSH in vitro.

The peroxisome-promoted activated receptor (PPAR) family of nuclear receptors, which consists of $\alpha, \beta$ and $\gamma$ isoforms, exerts a major role in the regulation of lipid and glucose metabolism (Uauy et al. 2000). The PPAR family are well-established heterodimeric partners for $\mathrm{RXR}$ in vitro, and granulosa cells express $\operatorname{PPAR} \alpha$ (Rodríguez et al. 2004). When activated by specific ligands (such as certain short-chain fatty acids), the PPARs triggers synthesis of enzymes related to lipid metabolism. Mohan et al. (2002) detected mRNA encoding for PPAR $\gamma$ in all stages of pre-attachment development in vitro, from the 2-cell stage to the hatched blastocyst. Transcripts were also detected in the oocytes, suggesting a likely role during IVM and fertilization. Expression of PPAR $\gamma$ during pre-attachment development and PPAR $\alpha$ in granulosa cells would indicate the presence of a heterodimeric partner for RXRs and highlight the complexity of the retinoid signalling pathway in the bovine embryo. Furthermore, events of lipid breakdown are coincident with blastocyst formation (i.e. TE differentiation) in mammalian embryos, and an increase of RA activity is characteristic of tissues undergoing active differentiation (Schweigert et al. 2002). Therefore, RA synthesis could request ROH freed from their esterified fatty acids, and PPARs could be involved in these mechanisms.

The recombinant product of the midkine gene has been found to enhance development to the blastocyst stage of bovine oocytes, its effect being mainly mediated by cumulus-granulosa cells during IVM (Ikeda et al. 2000a,b). Midkine has been isolated in bovine FF (Ohyama et al. 1994), and in rat granulosa cells in dependence on gonadotropins (Karino et al. 1995; Minegishi et al. 1996). As simultaneous addition of FSH and RA to a granulosa cell culture did not significantly change the accumulation of midkine mRNA observed with either FSH or RA alone (Minegishi et al. 1996), this effect could be associated with the suppression of FSH-R by RA (Minegishi et al. 1996,2000a). Midkine suppresses apoptosis in the bovine cumulus cells during IVM (Ikeda et al. 2005), and gene expression of midkine is enhanced by 9-cis-RA in these cells (Gómez et al. 2003). Therefore, reducing apoptosis in cumulus cells during IVM, which may positively correlate with the cytoplasmic maturation degree of the oocytes (Ikeda et al. 2003), is a possible mechanism of RA in cumulus cells via activation of midkine.

Retinoids can also modify gene expression by nontranscriptional procedures. Upon a 9-cis-RA treatment, 3' polyadenylation [poly-(A)] increases after meiotic arrest and decreased when these oocytes matured in vitro (Gómez et al. 2003). During oocyte growth, large amounts of mRNA are synthesized and polyadenylated in the nucleus in an essentially co-transcriptional procedure (Neugebaeuer 2002). Polyadenylation tails have been shown to regulate both translation and mRNA stability. The amount of poly-A in the oocyte is associated with a gain in the quality of mRNA stored in the ooplasm (Lonergan et al. 2003), and defective developmental competence is accompanied by abnormal poly-A levels (Brevini et al. 2002).

Genes involved in blastocyst activity and cell proliferation and apoptosis can be affected by RA. The composition and accumulation of fluid in the blastocoel is regulated by $\mathrm{Na} / \mathrm{K}-\mathrm{ATPase}$. In hatched blastocysts, $\mathrm{Na} / \mathrm{K}$-ATPase $\alpha 1$-subunit expression is influenced by inhibition of endogenous retinoid synthesis and by 
exogenous ATRA (Rodríguez et al. 2006). Similar changes were also observed in the expression of the p53 gene (Rodríguez et al. 2006), whose encoded protein becomes stabilized in response to stress or proliferative signals, causing cells to undergo either cell cycle arrest or apoptosis (Vousden and Lu 2002). However, the posthatching behaviour of the p53 gene might not be directly retinoid-dependent but rather a cell cycle arrest response to increased proliferation signals with proliferation being a consequence of retinoid treatment.

\section{Other Mechanisms for Retinoids in Bovine Reproduction}

The effect of BC contained in the follicle has been recently suggested to act as an antioxidant on the oocyte (Ikeda et al. 2005). This proposal has been yet unexplored in bovine, but it is based on increasing evidence of reactive oxygen species compromising cytoplasmic maturation (Hashimoto et al. 2000; Cetica et al. 2001; Ali et al. 2003; Iwata et al. 2003; Dalvit et al. 2005a,b). The protective effect of $\mathrm{BC}$ is probably independent on retinoid receptors, in contrast with a role for $\mathrm{RA}$ in the generation of oxidative stress in some cell types (CastroObregon and Covarrubias 1996; Mantymaa et al. 2000; Ahlemeyer et al. 2001). Nevertheless, we did not find signs of oxidative damage because of treatment with 9-cis-RA in meiotically inhibited and/or in vitro matured bovine oocytes (Gómez et al. 2004). In these oocytes the expression of genes coding for Mn-superoxide dismutase and glucose-6-phosphate dehydrogenase, enzymes involved in neutralization response against oxidative damage, did not change with 9-cis-RA.

In the cow, cyclooxygenase-2 (cox-2) is present in granulosa and cumulus cells and increases at periovulation time (Liu et al. 2002; Nuttinck et al. 2002). Inhibition of cox-2 during the pre-ovulatory period blocks ovulation (De Silva and Reeves 1985; Algire et al. 1992). As ATRA and 9-cis-RA suppress cox-2 transcription (Yang and Frucht 2001; Subbaramaiah et al. 2002) these molecules may contribute to reduce prostaglandin synthesis and thus enhancing cytoplasmic maturation (Ikeda et al. 2005). These authors also suggested a possible role of RA in regulating cytoplasmic maturation via the nitric oxide (NO)/NO synthase (NOS) system, based on inhibition of inducible NOS expression by RA in cumulus-granulosa cells through RAR $\alpha$ (Sirsjo et al. 2000). RA. In porcine oocytes, RA inhibits expression of endothelial NOS and NO synthesis (Hattori et al. 2002).

As derived from its effects on blastocyst development kinetics and proliferation, it is likely that retinoids can affect sex (as related to embryonic development kinetics) and ploidy (as dependent on increased proliferation; ploidy and proliferation: 5734 entries in pubmed). Through induction of Stra8 gene expression in embryonic mice ovaries, RA is responsible for meiotic initiation in female while it precludes its occurrence in embryonic testes until after birth (Koubova et al. 2006). Whether Stra8 gene is involved in sex and retinoid dependent mechanisms in mitotic initiation after embryonic genome activation is unknown. The above are interesting topics for future research.

\section{Conclusion}

Findings reported in this review corroborate some essential traits observed with retinoids in somatic cells: The supply of retinoid to the embryos must be ensured within a physiological range, both in length and in concentration, as both excess and deficiency of retinoid cause abundant teratogenic defects because of its pleiotrophic activity. On the other hand, manipulation of retinoid metabolism can lead to in vitro embryos with improved ICM and high ICM/total cell rates, which is a major objective in reproductive and stem cells technology. In agreement with Ikeda et al. (2005), it is possible that requirements of vitamin $\mathrm{A}$ are different in both conventional reproduction and in vitro procedures, which requires further clarification as long-term developmental competence of the oocyte can be directly involved.

\section{Acknowledgements}

The authors are granted by the project AGL2005-04479 (Spanish Ministry of Education and Science). Aida Rodríguez is a fellowship holder from the FPI programme (Spanish Ministry of Education and Science).

\section{References}

Ahlemeyer B, Bauerbach E, Plath M, Steuber M, Heers C, Tegtmeier F, Krieglstein J, 2001: Retinoic acid reduces apoptosis and oxidative stress by preservation of SOD protein level. Free Radic Biol Med 30, 1067-1077.

Algire JEA, Guilbault LA, Downey Shrikandakumar BR, 1992: Preovulatory changes in follicular prostaglandins and their role in ovulation in cattle. Can J Vet Res 56, 67-69.

Ali AA, Bilodeau JF, Sirard MA, 2003: Antioxidant requirements for bovine oocytes varies during in vitro maturation, fertilization and development. Theriogenology 59, 939-949.

Bagavandoss P, Midgley, AR Jr 1988: Biphasic action of retinoids on gonadotropin receptor induction in rat granulosa cells in vitro. Life Sci 43, 1607-1614.

Besenfelder UL, Solti J, Seregi M, Müller M, Brem G, 1996: Different roles for $\beta$-carotene and vitamin $\mathrm{A}$ in the reproduction of rabbits. Theriogenology 45, 1583-1591.

Blaner WS, Obunike JC, Kurlandsky SB, al-Haideri M, Piantedosi R, Deckelbaum RJ, Goldberg IJ, 1994: Lipoprotein lipase hydrolysis of retinyl ester. Possible implications for retinoid uptake by cells. J Biol Chem 269, 1655916565 .

Bonet ML, Ribot J, Felipe F, Palou A, 2003: Vitamin A and the regulation of fat reserves. Cell Mol Life Sci 60, 13111321.

Brevini TA, Lonergan P, Cillo F, Francisci C, Favetta LA, Fair T, Gandolfi F, 2002: Evolution of mRNA polyadenylation between oocyte maturation and first embryonic cleavage in cattle and its relation with developmental competence. Mol Reprod Dev 63, 510-517.

Brown JA, Eberhardt DM, Schrick FN, Roberts MP, Godkin JD, 2003: Expression of retinol-binding protein and cellular retinol-binding protein in the bovine ovary. Mol Reprod Dev 64, 261-269.

Bucco RA, Melner MH, Gordon DS, Leers-Sucheta S, Ong DE, 1995: Inducible expression of cellular retinoic acid- 
binding protein II in rat ovary: gonadotropin regulation during luteal development. Endocrinology 136, 2730-2740.

Castro-Obregon S, Covarrubias L, 1996: Role of retinoic acid and oxidative stress in embryonic stem cell death and neuronal differentiation. FEBS Lett 381, 93-97.

Cetica PD, Pintos LN, Dalvit GC, Beconi MT, 2001: Antioxidant enzyme activity and oxidative stress in bovine oocyte in vitro maturation. IUBMB Life 51, 57-64.

Chambon P, 1996: A decade of molecular biology of retinoic acid receptors. FASEB J 10, 940-954.

Chew BP, Holpuch DM, O'Fallon JV, 1984: Vitamin A and beta-carotene in bovine and porcine plasma, liver, corpora lutea, and follicular fluid. J Dairy Sci 67, 1316-1322.

Dalvit GC, Cetica PD, Pintos LN, Beconi MT, 2005a: Reactive oxygen species in bovine embryo in vitro production. Biocell 29, 209-212.

Dalvit G, Llanes SP, Descalzo A, Insani M, Beconi M, Cetica P, 2005b: Effect of alpha-tocopherol and ascorbic acid on bovine oocyte in vitro maturation. Reprod Domest Anim 40, 93-97.

Davidson TR, Ferguson CE, Wheeler MB, Godke RA, 2004: Apoptosis in the pre-implantation embryo. Embryo Transfer Newsletter, 4-9.

De Silva M, Reeves JJ, 1985: Indomethacin inhibition of ovulation in the cow. J Reprod Fertil 75, 547-549.

Dirami G, Massaro GD, Clerch LB, Ryan US, Reczek PR, Massaro D, 2003: Lung retinol storing cells synthesize and secrete retinoic acid, an inducer of alveolus formation. Am J Physiol Lung Cell Mol Physiol 286, 249-256.

Dolle P, Fraulob V, Kastner P, Chambon P, 1994: Development expression of murine retinoid $\mathrm{X}$ receptor (RXR) genes. Mech Dev 45, 91-104.

Duque P, Díez C, Royo LJ, Lorenzo PL, Carneiro G, Hidalgo CO, Facal N, Gómez E, 2002: Enhancement of developmental capacity of meiotically inhibited bovine oocytes by retinoic acid. Hum Reprod 17, 2706-2714.

Durston AJ, Timmermans JP, Hage WJ, Hendriks HF, de Vries NJ, Heideveld M, Nieuwkoop PD, 1989: Retinoic acid causes an anteroposterior transformation in the developing central nervous system. Nature 340, 140-144.

Eberhardt DM, Will WA, Godkin JD, 1999: Retinol administration to superovulated ewes improves in vitro embryonic viability. Biol Reprod 60, 1483-1487.

Ferguson EM, Leese HJ, 1999: Triglyceride content of bovine oocytes and early embryos. J Reprod Fertil 116, 373-378.

Gjorret JO, Knijn HM, Dieleman SJ, Avery B, Larsson LI, Maddox-Hyttel P, 2003: Chronology of apoptosis in bovine embryos produced in vivo and in vitro. Biol Reprod 69, 1193-1200.

Gómez E, Duque P, Hidalgo C, Facal N, Fernández I, Díez C, 2002: Enhancement of developmental capacity of meiotically inhibited bovine oocytes by retinoic acid. Theriogenology 57, 721 (abstract).

Gómez E, Royo LJ, Duque P, Carneiro G, Hidalgo C, Goyache F, Lorenzo PL, Alvarez I, Facal N, Diez C, 2003: 9-cis-retinoic acid during in vitro maturation improves development of the bovine oocyte and increases midkine but not IGF-I expression in cumulus-granulosa cells. Mol Reprod Dev 66, 247-255.

Gómez E, Rodriguez A, Goyache F, Diez C, Jose Royo L, Moreira PN, Caamano JN, Moran E, Gutierrez-Adan A, 2004: Retinoid-dependent mRNA expression and poly-(A) contents in bovine oocytes meiotically arrested and/or matured in vitro. Mol Reprod Dev 69, 101-108.

Gómez E, Rodríguez A, Alonso-Montes C, Caamaño JN, Royo LJ, Goyache F, Facal N, Ikeda S, Alvarez I, Díez C, 2006: Binding retinoid receptors by specific agonists affects the bovine blastocyst development in vitro. Reprod Fert Dev 18, 172. (abstract).
Gossen N, Hoedemaker M, 2005: Effect of beta-carotin serum concentration on the reproductive performance in dairy cows. Berl Munch Tierarztl Wochenschr 118, 326-333.

Gossen N, Feldmann M, Hoedemaker M, 2004: Effect of parenteral supplementation with beta-carotene in the form of an injection solution (Carofertin) on the fertility performance of dairy cows. Dtsch Tierarztl Wochenschr 111, $14-21$.

Griffith M, Zile MH, 2000: Retinoic acid, midkine, and defects of secondary neurulation. Teratology 62, 123-133.

Guillonneau M, Jacqz-Aigrain E, 1997: Teratogenic effects of vitamin A and its derivatives. Arch Pediatr 4, 867-874.

Haliloglu S, Baspinar N, Serpek B, Erdem H, Bulut Z, 2002: Vitamin $\mathrm{A}$ and beta-carotene levels in plasma, corpus luteum and follicular fluid of cyclic and pregnant cattle. Reprod Domest Anim 37, 96-99.

Hashimoto S, Minami N, Yamada M, Imai H, 2000: Excessive concentration of glucose during in vitro maturation impairs the developmental competence of bovine oocytes after in vitro fertilization: relevance to intracellular reactive oxygen species and glutathione contents. Mol Reprod Dev 56, 520-526.

Hattori M, Takesue K, Nishida N, Kato Y, Fujihara N, 2000: Inhibitory effect of retinoic acid on the development of immature porcine granulosa cells to mature cells. J Mol Endocrinol 25, 53-61.

Hattori MA, Kato Y, Fujihara N, 2002: Retinoic acid suppression of endothelial nitric oxide synthase in porcine oocyte. Can J Physiol Pharmacol 80, 777-782.

Hidalgo CO, Díez C, Duque P, Facal N, Gómez E, 2003: Pregnancies and improved early embryonic development in bovine oocytes matured in vitro with 9-cis-retinoic acid. Reproduction 125, 409-416.

Hidalgo C, Diez C, Duque P, Prendes JM, Rodriguez A, Goyache F, Fernandez I, Facal N, Ikeda S, Alonso-Montes C, Gomez E, 2005: Oocytes recovered from cows treated with retinol become unviable as blastocysts produced in vitro. Reproduction 129, 411-421.

Huang FJ, Wu TC, Tsai MY, 2001: Effect of retinoic acid on implantation and post-implantation development of mouse embryos in vitro. Hum Reprod 16, 2171-2176.

Huang FJ, Shen CC, Chang SY, Wu TC, Hsuuw YD, 2003: Retinoic acid decreases the viability of mouse blastocysts in vitro. Hum Reprod 18, 130-136.

Huang FJ, Hsu YC, Kang HY, Chang SY, Hsuuw YD, Huang $\mathrm{KE}, 2005$ : Effects of retinoic acid on the inner cell mass in mouse blastocysts. Fertil Steril 83, 238-242.

Huang FJ, Hsuuw YD, Lan KC, Kang HY, Chang SY, Hsu YC, Huang KE, 2006: Adverse effects of retinoic acid on embryo development and the selective expression of retinoic acid receptors in mouse blastocysts. Hum Reprod 21, 202209.

Ikeda S, Nishikimi A, Ichihara-Tanaka K, Muramatsu T, Yamada M, 2000a: cDNA cloning of bovine midkine and production of the recombinant protein, which affects in vitro maturation of bovine oocytes. Mol Reprod Dev 57, 99-107.

Ikeda S, Ichihara-Tanaka K, Azuma T, Muramatsu T, Yamada M, 2000b: Effects of midkine during in vitro maturation of bovine oocytes on subsequent developmental competence. Biol Reprod 63, 1067-1074.

Ikeda S, Imai H, Yamada M, 2003: Apoptosis in cumulus cells during in vitro maturation of bovine cumulus-enclosed oocytes. Reproduction 125, 369-376.

Ikeda S, Kitagawa M, Imai H, Yamada M, 2005: The roles of vitamin A for cytoplasmic maturation of bovine oocytes. J Reprod Dev 51, 23-35.

Ingenbleek Y, Young V, 1994: Transthyretin (prealbumin) in health and disease: nutritional implications. Ann Rev Nutr 14, 495-533. 
Iwata H, Ohota M, Hashimoto S, Nagai Y, 2003: Free oxygen radicals are generated at the time of aspiration of oocytes from ovaries that have been stored for a long time. Zygote 11, 1-5.

Iwata M, Hirakiyama A, Eshima Y, Kagechika H, Kato C, Song SY, 2004: Retinoic acid imprints gut-homing specificity on T cells. Immunity $\mathbf{2 1}, 527-538$.

Karino S, Minegishi T, Ohyama Y, Tano M, Nakamura K, Miyamoto K, Tanaka S, Ibuki Y, 1995: Regulation and localization of midkine in rat ovary. FEBS Lett 362, 147-150.

Kessel M, Gruss P, 1991: Homeotic transformations of murine vertebrae and concomitant alteration of Hox codes induced by retinoic acid. Cell 67, 89-104.

Klaassen I, Brakenhoff RH, Smeets SJ, Snow GB, Braakhuis BJ, 1999: Considerations for in vitro retinoid experiments: importance of protein interaction. Biochim Biophys Acta 1427, 265-275.

Koubova J, Menke DB, Zhou Q, Capel B, Griswold MD, Page DC, 2006: Retinoic acid regulates sex-specific timing of meiotic initiation in mice. Proc Natl Acad Sci 103, 2474 2479.

Lawrence JL, Payton RR, Godkin JD, Saxton AM, Schrick FN, Edwards JL, 2004: Retinol improves development of bovine oocytes compromised by heat stress during maturation. J Dairy Sci 87, 2449-2454.

Leroy JL, Genicot G, Donnay I, Van Soom A, 2005: Evaluation of the lipid content in bovine oocytes and embryos with Nile red: a practical approach. Reprod Domest Anim 40, 76-78.

Liu J, Carriere PD, Dore M, Sirois J, 2002: Prostaglandin G/H synthase- 2 is expressed in bovine preovulatory follicles after the endogenous surge of luteinizing hormone. Biol Reprod 57, 1524-1531.

Livingston T, Eberhardt D, Edwards JL, Godkin J, 2004: Retinol improves bovine embryonic development in vitro. Reprod Biol Endocrinol 21, 2-83.

Lonergan P, Faerge I, Hyttel PM, Boland M, Fair T, 2003: Ultraestructural modifications in bovine oocytes maintained in meiotic arrest in vitro using roscovitine or butyrolactone. Mol Reprod Dev 64, 369-378.

Mamo S, Ponsuksili S, Wimmers K, Gilles M, Schellander K, 2005: Expression of retinoid $X$ receptor transcripts and their significance for developmental competence in in vitroproduced pre-implantation-stage bovine embryos. Reprod Domest Anim 40, 177-183.

Mangelsdorf DJ, Borgmeyer U, Heyman RA, Zhou JY, Ong ES, Oro AE, Kakizuka A, Evans RM, 1992: Characterization of three RXR genes that mediate the action of 9-cis retinoic acid. Genes Dev 6, 329-344.

Mangelsdorf DJ, Umesono K, Evans RM, 1994: Cellular biology and biochemistry of the retinoids. In: Sporn MB, Roberts AB, Goodman DS (eds), The Retinoids- Biology, Chemistry and Medicine. Raven Press, New York, pp. 319349.

Mantymaa P, Guttorm T, Siitonen T, Saily M, Savolainen ER, Levonen AL, Kinnula V, Koistinen P, 2000: Cellular redox state and its relationship to the inhibition of clonal cell growth and the induction of apoptosis during all-trans retinoic acid exposure in acute myeloblastic leukaemia cells. Haematologica 85, 238-245.

Martínez-Bello JD, Fernández Sánchez I, Quintela Arias L, 2004: Parenteral $\boldsymbol{\beta}$-carotene administration on bovine embryo donors. A preliminary approach. Proceedings 20th Annual meeting Association Europeenne de Transfert Embryonnaire (AETE), Lyon, pp. 152.

McLaren DS, Frigg M, 2001: Vitamin A in health. In: Levenberger AF (ed), Sight and Life Manual on Vitamin A deficiency disorders (VADD), 2nd edn. pp. 21-30. (http:// www.sightandlife.org/booksSALpdf/00AllMan.pdf).
Mic FA, Molotkov A, Benbrook DM, Duester G, 2003: Retinoid activation of retinoic acid receptor but not retinoid $\mathrm{X}$ receptor is sufficient to rescue lethal defect in retinoic acid synthesis. Proc Natl Acad Sci 100, 7135-7140.

Minegishi T, Karino S, Tano M, Ibuki Y, Miyamoto K, 1996: Regulation of midkine messenger ribonucleic acid levels in cultured rat granulosa cells. Biochem Biophys Res Commun 229, 799-805.

Minegishi T, Hirakawa T, Kishi H, Abe K, Tano M, Abe Y, Miyamoto K, 2000a: The mechanisms of retinoic acidinduced regulation on the follicle-stimulating hormone receptor in rat granulosa cells. Biochim Biophys Acta 1495, 203-211.

Minegishi T, Hirakawa T, Kishi H, Abe K, Ibuki Y, Miyamoto K, 2000b: Retinoic acid (RA) represses follicle stimulating hormone (FSH)-induced luteinizing hormone (LH) receptor in rat granulosa cells. Arch Biochem Biophys 373, 203-210.

Mohan M, Malayer JR, Geisert RD, Morgan GL, 2001: Expression of retinol-binding protein messenger RNA and retinoic acid receptors in preattachment bovine embryos. Mol Reprod Dev 60, 289-296.

Mohan M, Malayer JR, Geisert RD, Morgan GL, 2002: Expression patterns of retinoid $\mathrm{X}$ receptors, retinaldehyde dehydrogenase, and peroxisome proliferator activated receptor gamma in bovine preattachment embryos. Biol Reprod 66, 692-700.

Mohan M, Thirumalapura NR, Malayer J, 2003: Bovine cumulus-granulosa cells contain biologically active retinoid receptors that can respond to retinoic acid. Reprod Biol Endocrinol 1, 104.

Morriss-Kay GM, Ward SJ, 1999: Retinoids and mammalian development. Int Rev Cytol 188, 73-133.

Neugebaeuer KM, 2002: On the importance of being co-transcriptional. J Cell Sci 115, 3865-3871.

Niederreither K, Subbarayan V, Dolle P, Chambon P, 1999: Embryonic retinoic acid synthesis is essential for early mouse post-implantation development. Nat Genet 21, 444448.

Nuttinck F, Reinaud P, Tricoire H, Vigneron C, Peynot N, Mialot JP, Mermillod P, Charpigny G, 2002: Cyclooxygenase-2 is expressed by cumulus cells during oocyte maturation in cattle. Mol Reprod Dev 61, 93-101.

Ohyama Y, Miyamoto K, Minamino N, Matsuo H, 1994: Isolation and identification of midkine and pleiotrophin in bovine follicular fluid. Mol Cell Endocrinol 105, 203208.

Parrow V, Horton C, Maden M, Laurie S, Notarianni E, 1998: Retinoids are endogenous to the porcine blastocyst and secreted by trophectoderm cells at functionally-active levels. Int J Dev Biol 42, 629-632.

Roberts C, Ivins SM, James CT, Scambler PJ, 2005: Retinoic acid down-regulates Tbx1 expression in vivo and in vitro. Dev Dyn 232, 928-938.

Rodríguez A, Royo LJ, Goyache F, Díez C, Morán E, Salas A, Gómez E, 2004: Bovine granulosa cells mRNA expression of peroxisome proliferator activated receptor- $\alpha$ $(\operatorname{PPAR} \alpha)$ and the proto-oncogene c-FOS. Reprod Fert Dev 16, 245. (abstract).

Rodríguez A, Díez C, Ikeda S, Caamaño JN, Alonso-Montes C, Royo LJ, Goyache F, Alvarez I, Facal N, Alvarez-Viejo M, Gómez E, 2006: Endogenous retinoid during the in vitro transition from bovine morula to blastocyst. Hum Reprod (in press).

Romert A, Tuvendal P, Simon A, Dencker L, Eriksson U, 1998: The identification of a 9-cis retinol dehydrogenase in the mouse embryo reveals a pathway for synthesis of 9-cis retinoic acid. Proc Natl Acad Sci 95, 44044409. 
Ross SA, McCaffery PJ, Drager UC, De Luca LM, 2000: Retinoids in embryonal development. Physiol Rev 80, 10211054.

Schweigert FJ, Zucker H, 1988: Concentrations of vitamin A, beta-carotene and vitamin $\mathrm{E}$ in individual bovine follicles of different quality. J Reprod Fertil 82, 575-579.

Schweigert FJ, Eisele W, 1990: Parenteral beta-carotene administration to cows: effect on plasma levels, lipoprotein distribution and secretion in the milk. Z Ernahrungswiss 29, 184-191.

Schweigert FJ, Rambeck WA, Zucker H, 1987: Transport of beta-carotene by the serum lipoproteins in cattle. J Anim Physiol Anim Nutr 57, 162-167.

Schweigert FJ, Siegling C, Tzimas G, Seeger J, Nau H, 2002: Distribution of endogenous retinoid, retinoid binding proteins (RBP, CRABPI) and nuclear retinoid X receptor beta (RXRbeta) in the porcine embryo. Reprod Nutr Dev 42, 285-294.

Shaw DW, Farin PW Washburn SP, Britt JH, 1995: Effect of retinol palmitate on ovulation rate and embryo quality in superovulated cattle. Theriogenology 44, 51-58.

Shenefelt RE, 1972: Gross congenital malformations. Animal model: treatment of various species with a large dose of vitamin A at known stages in pregnancy. Am J Pathol 66, 589-592.

Sirsjo A, Gidlof AC, Olsson A, Torma H, Ares M, Kleinert H, Forstermann U, Hansson GK, 2000: Retinoic acid inhibits nitric oxide synthase- 2 expression through the retinoic acid receptor-alpha. Biochem Biophys Res Commun 270, 846851.

Sive HL, Draper BW, Harland RM, Weintraub H, 1990: Identification of a retinoic acid-sensitive period during primary axis formation in Xenopus laevis. Genes Dev 4, 932-942.

Song Y, Hui JN, Fu KK, Richman JM, 2004: Control of retinoic acid synthesis and FGF expression in the nasal pit is required to pattern the craniofacial skeleton. Dev Biol 276, 313-329.

Sporn MB, Roberts AB, 1991: Interactions of retinoids and transforming growth factor-beta in regulation of cell differentiation and proliferation. Mol Endocrinol 5, 3-7.

Subbaramaiah K, Cole PA, Dannenberg AJ, 2002: Retinoids and carnosol suppress cyclooxygenase- 2 transcription by CREB-binding protein/p300-dependent and -independent mechanisms. Cancer Res 62, 2522-2530.

Thaller C, Eichele G, 1987: Identification and spatial distribution of retinoids in the developing chick limb bud. Nature 327, 625-628.
Thouas GA, Korfiatis NA, French AJ, Jones GM, Trounson AO, 2001: Simplified technique for differential staining of inner cell mass and trophectoderm cells of mouse and bovine blastocysts. Reprod Biomed Online 3, 25-29.

Uauy R, Mena P, Cecilia R, 2000: Essential fatty acids in early life: structural and functional role. Proc Nutr Soc 59, 3-15.

Ulven SM, Gundersen TE, Sakhi AK, Glover JC, Blomhoff R, 2001: Quantitative axial profiles of retinoic acid in the embryonic mouse spinal cord: 9-cis retinoic acid only detected after all-trans-retinoic acid levels are super-elevated experimentally. Dev Dyn 222, 341-353.

Vousden KH, Lu X, 2002: Live or let die: the cell's response to p53. Nat Rev Cancer 2, 594-604.

Wardlaw SA, Bucco RA, Zheng WL, Ong DE, 1997: Variable expression of cellular retinol- and cellular retinoic acidbinding proteins in the rat uterus and ovary during the estrous cycle. Biol Reprod 56, 125-132.

Whaley Sl, Hedgpeth VS, Britt JH, 1997: Evidence that injection of vitamin A before mating may improve embryo survival in gilts fed normal or high-energy diets. J Anim Sci 75, 1071-1077.

Whaley SL, Hedgpeth VS, Farin CE, Martus NS, Jayes FC, Britt JH, 2000: Influence of vitamin A injection before mating on oocyte development, follicular hormones, and ovulation in gilts fed high-energy diets. J Anim Sci 78, 15981607.

Xing W, Sairam MR, 2002: Retinoic acid mediates transcriptional repression of ovine follicle-stimulating hormone receptor gene via a pleiotropic nuclear receptor response element. Biol Reprod 67, 204-211.

Yang WL, Frucht H, 2001: Activation of the PPAR pathway induces apoptosis and COX-2 inhibition in HT-29 human colon cancer cells. Carcinogenesis 2001 22, 1379-1383.

Zheng WL, Bucco RA, Sierra-Rievera E, Osteen KG, Melner MH, Ong DE, 1999: Synthesis of retinoic acid by rat ovarian cells that express cellular retinoic acid-binding protein-II. Biol Reprod 60, 110-114.

Zile MH, 2001: Function of Vitamin A in vertebrate embryonic development. J Nutr 131, 705-708.

Submitted: 05 May 2006

Author's address (for correspondence): Enrique Gómez, Servicio Regional de Investigación y Desarrollo Agroalimentario (SERIDA), Área de Genética y Reproducción, SERIDA, Camino de los Claveles 604, 33203 Gijón, Asturias, Spain. E-mail: egomez@serida.es 